Fecha de recepción: marzo 2020 Fecha de aceptación: abril 2020 Versión final: mayo 2020

\section{Bringing your Image Consulting Practices up to industry sustainability standards}

Neha Malhotra ${ }^{(1)}$

\begin{abstract}
The purpose of this article is to define the Industry sustainability standards prevailing in the Image Consulting Industry to help you meet up to those standards and gain success in your Image consulting profession. It's never too late to start working on the Brand value of your Business and bring it up to the highest standards prevailing in the industry. Image Consulting is about growing your Business through brilliant ideas and right tools. As an Image Consultant, Let your Image reflect the extraordinary side of you. In this article we will share hands on experience of successful Image professionals from the industry with the readers to give a realistic glimpse of their journey from start to finish, helping you develop your own business. This article aims at helping the readers understand the dilemmas and dynamics of the market and work towards promoting a sustainable Business.

We will also be sharing various Business options and choices to build your business around it.
\end{abstract}

Keywords: Image Consulting - celebrity stylist - industry standards - brand value - Sustainability standards - Image management - Image consultant - successful business.

[Abstracts in spanish and portuguese on the page 78]

(1) Neha Malhotra, AICI . CIP. Neha Malhotra is the Founder of Core Impression Training, India's leading Image Consulting Training Institute Providing Professional Image Consulting Courses since 2014. Neha is India's First AICI Certified Image Consultant. She has opened gateway for many aspiring Image consultants in India to pursue this career professionally.

Neha Malhotra is the Founder of AICI India, one of the largest association of Image Consultants Worldwide. Neha is an Internationally trained and certified Image Consultant \& Master Trainer trained from The Imagemaker Inc. ${ }^{\circledR}$ headed by Dr. Joyce Knudsen, AICICIM.

With 16+ years of extensive and diverse experience in the Aviation \& Training industry by her side, she has proven her mettle as a great mentor and trainer in the Image industry. She has served a term of 3 years as President of AICI India Chapter (2016-2019) and has won numerous accolades. Neha is a Master in Business Administration (MBA) with intricate specialization in Human Resource Management. She is well versed with people skills. She has a sensitive approach towards accessing the needs of the clients and believes in making their Image consulting journey an experience. 
Neha has launched the Image Consulting Certification Program in India to cater to the niche where quality \& standards are of utmost importance.

Our definition of Sustainability standards is defined for this abstract and used interchangeably with other words such as rational, reasonable, and acceptable legitimate.

\section{The brief}

An Image Consultant works on client makeovers, guide them on the right wardrobe to suit their personality, go on shopping expeditions with clients and even recreate their wardrobe. The Image Consultant identifies and explains the right style and colours based on the client's body type, natural colouring, profession and their personality.

An image consultant understands the requirements of the client in sync with what kind of image they want to project and provide them with solutions accordingly. You coach the clients on various aspects from hair and makeup advice to effective body language and self confidence.

As an Image professional you can:

- Choose to work with individual clients; you will advise the clients on hair styling, makeup, instructions on effective body language and building up self confidence.

- You may choose to become a full time makeup artist and offer makeup services.

- You can work with corporate clients by coaching them on tactics for better sales and customer relations.

- You can even work with celebrities, as a celebrity stylist for styling their aesthetics to manoeuvre their looks on various occasions to present their dynamic personality.

- You can work from home; you can start part-time business with low costs, which is often creative and satisfying.

Take the lead and help your clients in transforming the way carry themselves by enhancing their personality and creating an impeccable image.

\section{Requirements to become an image consultant}

As an image consultant, you'll need to have an innate sense of style and up to date knowledge of fashion, style, hair and makeup trends in both personal and professional settings. You'll also have to stay abreast with the latest conventions in big and small business conduct. You are expected to be kind in an empathetic way. Last but not the least, this is a practice-what-you-preach business i.e. you'll have to look polished, professional and dressed for success on all public occasions and otherwise.

Make it a habit to stay well groomed and up-to date every day. 
It calls for respecting individuals, appreciating beauty in addition to having an interest for developing human potential. Further having an aesthetic eye for style, colour and design are an added advantage that would help you in turning out to be a successful Image Consultant with the fullest potential.

Few of the many characteristics of booming image consultants include:

- passion and determination

- strong communication skills

- being watchful

- well-organized

- consistently presentable

- last but not the least diplomatic yet objective

\section{Find your niche \& build your business around it}

Let's begin by understanding Image consulting industry in depth. Image Consulting is a very dynamic industry comprising of professionals from diverse industry backgrounds and experiences. They have excelled in their area of expertise and developed their skills as a mentor, trainer or influencer. Image consulting is all about developing your own potential and sharing the same insight with others. It is about helping them add value to their personal and professional lives.

To begin with,

- You have to find your niche and your best skills followed by exploring them to the fullest to be able to get the best results.

- Put First Things First, you have to first prioritize and then narrow down your target audience / client base, and accordingly, learn how to develop your business around them.

- Start strategizing on what your audience / client base is looking for.

- Build your business around them providing solutions as per their requirements.

- Be tactical to ensure that you find the best ways for cost saving to get the maximum output from minimum resources.

\section{How I chose my Niche and established my Brand?}

Post completion of my Image Consulting training, I kick started my business as a professional Image Consultant with the brand name Neha Malhotra (a very individualistic name that meant more of me). I was offering all my services under my name through my website www.nehamalhotra.com

At the initial stages, the scope of services was broadly categorized under

- Individual consultation 
- Group workshops and

- Professional image consultation

I was catering to the needs of both individual as well as corporate clients at a time when the niche was new and so was I. However, in the due course, the nature of work enquiries gradually shifted from individual consultation to more of corporate and professional ones.

The time was ripe to self analyze and undertake a thorough research of the market to comprehend how well we pallied. There was beyond any doubt scarcity of Image Consulting training companies with International Accreditation in India. The demand for Image Consulting Courses was on a rise rather at its peak leaving a huge gap in the demand and supply of training resources to fulfill the requirements of the industry.

This happened to be the turning point in my journey as an Internationally Certified Image Consultant. It was time to share my knowledge and experiences as an Image Consultation at a broader and tailor-made level.

Some crucial decisions, I took at this stage, in the interest of my Business:

- I narrowed down the scope of my services. I was confident about the choice of my business niche i.e. offering professional image consulting courses.

- I started exploring the sources of my potential clients and researched about what exactly are they looking out for, from a professional training provider in India. To list a few findings, I learnt that aspiring image consultants in India are a segment of those professionals who are;

-Looking for a change in their present work scenario including existing as well as new employees and employers.

-Ladies who are new mothers and are cannot continue with the 9-5 work scenario.

-Professionals who do not want to be in time-bound professions and would like to work at their ease and convenience.

-People facing mid career crisis and are looking forward to change their industry.

-They are looking for professional courses with International affiliation.

-They were finding the courses offered by International Training companies a bit over board in terms of course fee and related expenses.

-They were looking out for a program that would equip them to get started with their practice at the earliest.

- I, then, prioritized my target audience and categorized them in terms of gender, age group, industry experience etc. The aim was to focus on the right platforms of marketing to tap the untapped target audience.

- Another realization at that point of time was that my present website needed a revamp moving towards a more crisp and build-to-suit framework to ensure the potential clients do not get confused.

This is what led to my dream come true of launching my own company with a new brand name. Incorporation of CORE IMPRESSION (my new brand) was followed by creating a new website with a new perspective to suit the industry needs better. 
Launching Core Impression Training was with the specific purpose to render Professional Image Consulting Courses in India, with accreditation from AICI in association with a AICI - CIM partner Dr. Joyce Knudsen AICI-CIM.

- Core Impression brand was incorporated to facilitate it for the aspirants to pursue an Image consulting course with international standards in India at an affordable price.

- This decision to contribute towards developing and promoting Image Consulting made me the founder of India's First Image consulting training company to be offering professional courses of International repute.

Synopsis: One has to be proactive and conduct a thorough research before deciding upon the core decisions for the success of the business. Carefully formulate marketing strategies to put across your brand rightly to the target audience. Discover how you can understand your clients and offer them what they need in a way that works for them, which may be quite different from what you prefer.

\section{Build your profile}

In the field of Image Consulting, "We work as educators and ambassadors for our own business" (Neha Malhotra, AICI-CIP).

Our online presence is a reflection of our brand offline. As an Image Consultant, "we advocate that improving one's image can improve one's life." It is of utmost importance for an Image professional to portray their best image on social media in sync with their brand value. It is essential to make a powerful first impression using components that convey trust, rapport and connection.

Image consulting and fashion styling is one the most glamorous and entertaining professions. If you have the passion for fashion and training, then a career as a stylist / Image consultant should be perfect for you.

Since this profession is about guiding others on becoming more successful in all walks of life, the profile of the person goes a long way to determine the target market segment and fee charged. For the purpose of understanding earning potential we have created 3 profiles and the individual needs to choose the profile that describes them the most.

Profile 1: An individual who does not have much or any professional work experience, comes from an average income group background and exposure level.

Profile 2: An individual who has about 3 to 5 years of work experience in corporate in sales and marketing, PR, customer service and similar fields and comes from higher than average income group background and exposure level.

Profile 3: An individual who has 5 to 15 years of experience in aviation and hospitality, media and entertainment, acting and modelling, sales and marketing, fashion related, customer service and other similar fields and comes from a high income group background 
and exposure level Based on the profile an average fee is projected which ranges between Rs. 1000 to Rs. 1500 per hour of work and the starting fee increases by $25 \%$ with each passing year.

During the initial stages of my career as an Image consultant I had put in a lot of effort to build up a strong profile. I followed the principal of inclusivity and added every big and small project I had undertaken in my portfolio (Neha Malhotra AICI - CIP).

- At Core Impression Training, we start working on building the profile of a student from the very first day of their training.

- A detailed brainstorming session is conducted to analyze the strengths and weaknesses of the student.

- Their professional profile is carefully created purely based upon their strengths.

- The past experience of the student is given a lot of emphasis. This also helps us to figure out future scope of career possibilities for that student.

Synopsis: The process of creating your profile is very crucial for your future business prospects yet complex too. This stage of your career has a direct effect on the kind results yu will get in future. One has to focus on their strengths and assets to their advantage and put it forward for success of Business and career as an image consultant.

A recent research has proven that majority share of sustainable business in Image Consulting comes from social media marketing.

- $58 \%$ of the total business was generated from leads generated from online marketing and promotions (Advertising on Facebook, Instagram, Google Ads etc.)

- $22 \%$ of the business was generated from promotions done at networking forums

- Referrals and returning clients generated $12 \%$ of the total business

- $8 \%$ business leads were generated from offline marketing and promotion (Newspapers, Magazine etc.)

\section{Image Consulting Business}

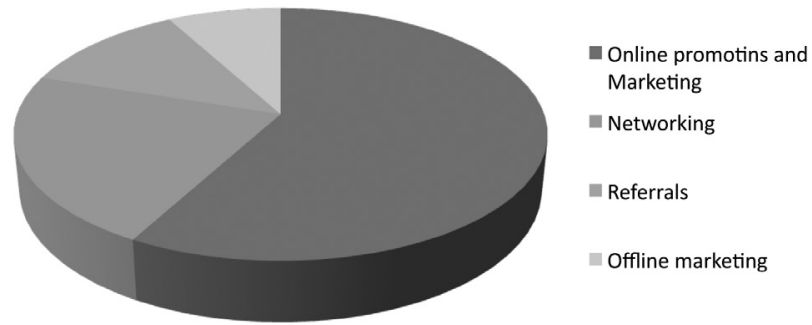


1. See and be seen on social media platforms: In today's world, your presence on social media is of utmost importance to be able to run a sustainable business. Various Social media platforms like Facebook, Instagram, LinkedIn, Twitter etc. are highly trending. Every individual or company has an account on at least two of such platforms.

People presume your brand to be, the way they see it online. There is a major scope for getting business by showcasing your brand on various social media platforms. You, just, have to carefully choose the most appropriate medium for marketing your brand online. Present the best version of your work profile to the target audience. Follow some guidelines to be able to market your brand on social media and run a successful business.

- The details you mention in your profile must be same across all social media platforms. Not to forget, they should be genuine with facts.

- Your profile should not be confusing; your brand should be able to provide direct solution to the requirement of your client base.

- Clearly outline the services/products that you offer. Highlight the purpose of your brand existence. For e.g. An Image Consulting Training Company should call for action "Become a certified Image consultant" every 2-3 days. So that the main purpose of existence of their business remains active.

- Collaborate with a professional marketing expert or hire a good marketing company. They will design and curate professional content and images for your business accounts.

- Build a story line around your business. Instagram stories are trending these days. You can even choose to share your own professional journey so that your clients can relate to it. - Invest in advertising on these platforms. You can opt for promotions through Google ads. You may even pay for advertising on Facebook and Instagram.

- Your audience would love to hear from you. Record videos and talk to your potential clients. Share your struggles and achievements through videos.

2. The importance of networking: Image consulting business can be conducted with returning clients and referrals which is a great asset toward achieving work-life balance. However, to become a familiar face in your industry, it's best to get out and about.

There is a constant need for networking in the Image consulting industry. As an Image professional we work in association with professionals from parallel industries. For example, to provide 100 percent styling solution to a client, you can collaborate with professional makeup artist or hairstylist to provide comprehensive solution based service to the client under one brand name.

A successful networking strategy is a stepping stone to synergize great associations and collaborations.

Merriam -Webster defines networking as "the exchange of information or services among the individuals, groups or institutions.” Networking can be successful only if it's a positive experience not negative."

There are many free events that provide fruitful opportunities for networking that exist in and around the area. Book Launch events, workshops, fashion and lifestyle exhibitions, brand launch parties, business networking forums etc are few examples to build up a great business through networking. 
Networking is an art. For some people networking is a gift. For most of us, it's a learned skill vital to professional and personal growth. Listed below are few guidelines for successful networking.

- Do not shy away from interacting with new people. During the function, don't hold back from cheerfully introducing yourself to fellow attendees.

- Start small, be a source of information and knowledge for your colleagues in your own company across departments.

- Get connected with local networking forum / groups around your workplace or city.

- Keep yourself updated about the upcoming events and try to offer to them any of your services / workshop at minimal cost to get a chance to demonstrate glimpses of your work.

- Strive to schedule at least one networking event in your calendar each week.

- Exchange business cards, and always follow up with a personal email and LinkedIn connection.

- Follow up with individuals with whom you found a common interest.

- Whether a potential prospect or simply a supporter, your aim is to let them know that a person with your unique set of skills is only a phone call away.

One of the trainees at Core Impression pursuing the Professional Image Consulting course had taken a break for almost 6 years from her previous job as a senior marketing professional. She was not sure how exactly she should begin her career again post completion of the course.

- Throughout her training with us, she was guided to start listing down the contact details of all the corporate clients she was in connect with during and post leaving her previous job.

- Once her professional profile was created, we suggested her to start networking with those clients to mark her comeback and update them about her newly acquired skills as an Image Consultant.

- She was also suggested to join major networking groups in her city so that she could meet professionals from various domains and introduce herself as an Image consultant who offers services to individuals as well as corporate clients.

"Networking is an intangible asset that you can use to your benefit to reap out tangible results" (Neha Malhotra AICI-CIP).

- In a span of 5 months, she had already got connected with almost 4 networking forums and had started getting regular business through her effective referral program.

Image consulting is relatively a new industry in India and not many people are aware of it. It is very important to get out there and tell people who we are and we do. Networking has played a very important role in spreading awareness about Image Consulting worldwide. 
Networking is not short lived, it's a lifelong process. You cannot expect great results overnight. Networking pays off after months and years of establishing connections and investing into relationships.

\section{Speak up and stand out: develop your public speaking and presentation skills for self} promotion

If public speaking excites you, take advantage of myriad opportunities available, reach out to groups of all kinds and offer them speaking sessions on the topics you are a master at. Keep learning and adding value to your existing knowledge every day. This is also known as "Sharpening the Saw". To be successful as a presenter you have to master the art of public speaking. Not only that; in today's competitive world where change is constant, it's not the time to just talk but to walk the talk for building up long lasting business relationships. "A business expands or shrinks in direct proportion to ones brand value".

According to research polls, the greatest fear most people have is the terror of speaking in front of public.

There are many ways for individuals, companies and businesses to gain respect, fame, market share and media attention. Self promotion is not restricted to few minutes of fame; it's much more than that. There are a variety of self promotion methods ranging from small community workshops to being a keynote speaker at some professional convention. Let us see how Core Impression assisted one of its students to brush up her skills and climb up the corporate ladder. She was a Professor of Spanish language with a renowned university.

- We guided her to utilize her student groups and offer them free image training short sessions and demonstrate them about the benefits and essence of image consulting.

- She started offering free image counseling sessions as well as short workshops to a group of students.

- She started getting requests for conducting more and more such sessions where students were ready to even pay for the sessions.

Her Public speaking skills worked very well for her to build up a foundation towards a new career path.

You can utilize some effective public speaking strategies listed below to build up brand meeting up industry's sustainability standards.

- Volunteering to deliver your presentation at a public gathering is one of the most effective and economical method of displaying your skills, hence increasing your brand value. - Strategically choose and shortlist few events where you can deliver some kind of presentation in your area of expertise.

- Become active in your professional organizations and other professional groups. You can always lookout for a public speaking platform while being associated.

- Image professionals can consider joining AICI (Association of Image Consultants International), one of the largest and the most prestigious association for Image profession- 
als worldwide. AICI provides immense opportunities to conduct workshops and trainings for members voluntarily. This helps you to sharpen your speaking skills.

- Self promotion is an art of getting positive attention for yourself or your brand with creativity and professionalism.

- Develop a reputation of a versatile professional instilled with a great zeal to take up voluntary projects for the betterment of the industry.

Public speaking skills are not just for special times and special projects. Every time we greet people or put a point across at a meeting or take a client out for lunch we are promoting ourselves.

\section{Work with clients \& build your technical skills}

Image Consulting is fun when you actually start practicing as an Image consultant. Working with clients gives you an opportunity to explore your career and strengthen your acquired skill set as an Image professional. An Image consultant transforms lives. They are constantly working on various aspects of their client's image to make them look and feel beautiful inside out.

Human resource is most complex resource around. Dealing with people and assessing them based on their skills is a highly complex process as it covers both objective and subjective aspects of a person's personality.

Image is a combination of internal as well as external aspects of Image of an individual. Image of an individual is a combination of their

- Appearance

- Behavior

- Communication

\section{External aspects of Image}

Appearance is the most important aspect of one's image. Our first impressions are formed majorly based on appearance. It includes many external aspects such as the type of clothing, styles of clothing and accessories, makeup, hairstyles, colors, hygiene and overall state of grooming. These are essential components for creating powerful first impression that conveys trust, rapport and connection.

\section{Internal aspects of Image}

Behavior is the combination of body language, non verbal communication, actions, postures, gestures and state of manners. The non verbal communication is a validation of the first impression and is used to create a sustainable long lasting one. Behavior of a person is truly based on ones journey of life, experiences \& education.

The building blocks of one's behavior are other internal aspects such as motivation, attitude, self esteem and confidence. 
Communication is the essence of successful image. In the world of change, building personal and business relationships is the key to success. Communication can be done in the form of verbal, non verbal or written communication. It includes various modes of communications such as, emails, letters, phone calls, voice mails etc.

"Think before you speak; pronounce not imperfectly, nor bring out your words too hastily, but orderly and distinctly" (Manners Culture and Dress, 1890).

\section{Image Consulting / Fashion Designing}

Often Image consulting is confused with fashion designing. A lot of people ask me, 'Are you a fashion designer?' to explain the difference between both the terms, I simply tell them - A Fashion Designer designs a garment, An Image Consultant chooses the garment that suits best for the color, body type, style and personality of the client. We also consider the roles and goals to be fulfilled by the client and the kind of impact the client would like to leave on their audiences.

Image Consulting is a process of change. Like any other process it has stages and steps involved. Carefully analyzing and accessing your client's requirement at every stage will help you as a brand reach out to the next level of success and client satisfaction. You may be working for an individual client or company, the process of consultation will be applied universally for all.
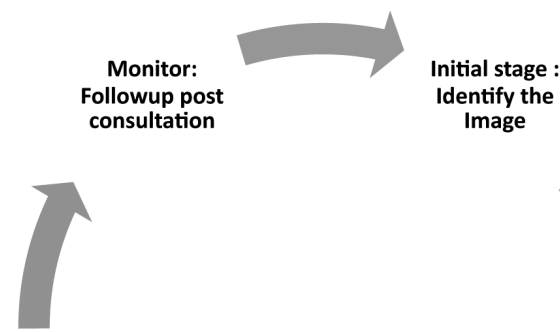

dentify the

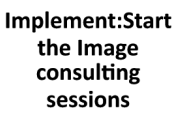

Exploration:

Find out the

details

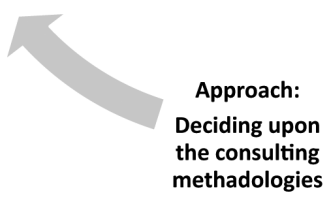




\section{Initial Stage: Identifying existing Image}

The Process of Image Consulting begins with identifying the present state of Image of the client and carefully analyzing the history of the client. This stage requires analyzing the minutest details pertaining to the past history and future requirements of the client. Every Image Consulting session begins with a reason for change. The client is usually looking for solution for some problem he/ she is trying to overcome. It is very crucial to build a rapport with your client at this initial stage. Once the client has built up trust in you as an individual they will definitely hire your brand for your services.

At this stage:

- You can identify that problem or reason by asking relevant questions to the client.

- You may reframe or rephrase the questions differently to get better details and insight to the pertaining issue.

- Many Image Consultants request the clients to fill up pre consultation forms way before the initial meeting too. These forms can be designed in a questionnaire form where you can get many details without having to ask them face to face.

- You will even get to know if your client is hesitant to open up or take up your services by the way they fill up the form.

At Core Impression Training, our first encounter with the client is usually on a call. "I make sure the person who attends to the call is well versed with the details of the courses and services that we offer. If required I personally get in touch with the client to find out their requirements. I also try and find out if all their questions and queries were answered and if they need any further information. This way I build a rapport with them initially even before meeting them in person."

\section{Exploration Stage: Find out the details}

The initial stage of the process has laid a foundation for you as a consultant to understand your client in more details. At this stage it is very important to win over the confidence of the client. The foundation of human interactions hasn't changed over centuries; the more understood someone feels, the more they would like to work with you.

This stage could be your initial meeting with the client.

- Be at your professional best, make a great first impression.

- Choose to plan out your meeting in a very professional environment. The client's decision to work with you is purely based on your initial encounter with them.

- Project the image of a confident, competent and credible professional to work with.

- Your listening skills play a very important role at this stage in helping you find further details and history of the client.

- Demonstrate your mastery of Business etiquette by putting your social skills to work for you.

- Be courteous and empathetic while listening to the client.

- Never pass any judgments on choices and thoughts of the client. 
- Be warm and welcoming.

"Once the client is convinced with the initial conversation, I usually suggest them to plan for a meeting, this way it gives us a chance to meet the persona and leave an impression about our quality and standards of services. This stage is very crucial as the prospect of the business largely depends on your first meeting and the kind of impression has been formed. I prefer a meeting in my office itself. In case the client is unable to come at my office then we choose a central venue for the meeting, usually Cowork office to have a professional environment for the meeting."This meeting clarifies and helps us understand the actual purpose of the client's requirement. My whole focus during this meeting is to be a good listener. I pay attention on small details which are more evident in their body language. I then offer them appropriate solutions. The entire process of consulting is then explained to them."

\section{Approach: Deciding upon the consulting methodologies}

This stage requires you to go one step forward to find out the reasons and explanations to your findings of the previous stages. Based on the results of your pre consultation and initial meeting with the client you can design and customize a plan and work with them to bring in a sustainable transformation and make them look and feel beautiful inside out. Every client may not have the same requirements.

You may consider the following guidelines to be successful at this stage

- Carefully list all the requirements of the client.

- Prepare a detailed consolidated list of all the services you offer.

- Include all the big and small details pertaining to the service.

- Share the list of all services and be willing to make changes if the client is looking for something else.

- Customise the services and offer a package of the selected services.

- Be open to listen to the client feedback and gather important information so as to rework your consulting sessions around it.

- Offer them what they need in a way that works for them, which may be quite different from what you prefer.

- Give a personal touch to the whole journey of their image transformation.

- Strive to make it an experience where the client feels understood and important.

- Plan the schedule of the training as per the plan.

"As we go further and as per my experience in the Industry, not every client has a similar requirement. I am always ready to customise our service plans to suit the needs of the client. We also take into consideration the time availability of the client to make our training and services more accessible." 


\section{Implement: Start the Image consulting sessions}

This stage is the actual phase where your practical training as an Image Consultant comes into picture. It is advisable to be ready with all your consulting and analysis resources well before you start practising. It is advisable to prepare your Image consulting kit during your professional training. A standard Image Consulting kit will include the following

- Your company / brand stationery which includes, your visiting cad, letterhead, envelopes, brochure and leaflets etc.

- Registration and feedback forms.

- Client analysis sheets and resources. This includes, Body measurement sheet, lifestyle analysis sheets, Colour analysis sheets \& handouts, Body type analysis sheet, face shape analysis sheet, personality type indicators sheets, wardrobe clustering sheets, personal shopping evaluation and inventory procurement sheets etc.

- Well maintained colour analyses drape kit with seasonal drapes and flags. You can buy from any leading colour analysis resource brand or choose to create your kit using fabrics available in the market.

- Complete makeup kit which includes a wide range of products suitable for various skin types and complexions. You will need this kit to demonstrate to your client the effect of makeup on their overall look.

- Mirror with lights which will be used during the makeup and styling session.

- Set o scarves and other accessories to demonstrate its use as resources for power dressing.

\section{"Practise makes a man perfect"}

- If you a beginner practise a few mock sessions in advance before the actual session with the client. This will give add finesse to your skills and your knowledge.

- You will also get a good hold over the flow of your whole session.

- Practise using all the resources from your kits, so that you are comfortable while using the same with your paid clients. I usually call over a friend for a coffee and offer them a free consultation session. This way it's a win situation, where I get to try my resources and same time a friend gets demonstration of the services I offer. During this process I also discover if there are any faults with my analysis sheet and if any changes are required.

- You may want to add on to your kit some equipment at a later stage when your business starts growing. A computer software to demonstrate virtual styling and to create look books for your clients. You may even want to have your own set up for photography and recording your client sessions for marketing and promotional activities.

At core Impression, we use the Image Consulting material of International standards. We keep all our analysis sheets and equipment ready before the arrival of the client. Our clients have a great experience consulting with us. We make sure their image consulting journey is a wonderful lifetime experience for them."

Begin working with your clients and strive to make a good rapport with them during the sessions. This ensures the client has a pleasant experience working with you. A word of mouth contributes to a lot of business in the Image consulting industry. 


\section{The final Stage: Monitor: Follow up post consultation}

The process of Image Consultation does not just end with the session itself. It is recommended to have a proper follow up procedure post consultation. You should end your session with a detailed feedback form. Insist your client to leave a genuine feedback about their experience working with you. This will not only help you to identify the shortcomings of your session, but also you will be able to develop better consulting techniques for your future Image Consulting sessions.

Always offer your clients to write a testimonial for you. This is a valuable source of direct feedback from the client.

You will work as a mentor and coach for certain agreed time period to make sure the client is able to implement the solutions offered during the sessions.

For example: On completion of the consultation sessions,

- I send out a detailed consultation summary to the client that has the synopsis of all the sessions.

- Every little detail of the session is mentioned. Starting from his / her lifestyle analysis, body type analysis, and colour seasons and style inclination etc.

- A detailed description of their personality traits is mentioned.

- A list of suggested products for skin care, hair care etc, are also mentioned.

- I personally get in touch with the client to find out their feedback about the services.

- I also make sure to ask them if they are using the recommended products and how they like it.

This process helps me to add a personalized touch to my services.

\section{Marketing your business}

Image consulting is an ongoing life long process. It is a universal market segment having gained popularity over the years. Almost everyone needs image management strategies to equip themselves in these skills successfully. Growth in any walk of life is about getting ample of opportunities from the desired market segment and to deliver results excelling the market sustainability standards.

"Stopping marketing to save money is like stopping your watch to save time" (Henry Ford). Don't stop marketing. If you want a full-time business, then you have to market your services all the time since you are not actually seeing clients (or developing a product/ program). You are never going to grow a business doing two hours of marketing a week. How you do it is up to you. You may want to write blogs, or share informational posts on social media platforms, or you may be interested in joining networking forums, the focus is on continuity of marketing of your business. Do what is right for you.

If you are a startup in Image consulting, Feedback is more important than customers. The faster you can resolve customer concerns and provide them a solution, the more likely you 
are to win over the long run. Few essential aspects of laying the foundation of an aggressive marketing plan are

- Solution based services that can market for you

- Percentage of conversion rate optimization

- Sponsored marketing on social media (Facebook and Instagram) to understand the industry specific consumer trend

- Client feedbacks

- Innovation in methods to reach target audience

- Adaptability and flexibility to the changing market scenarios

- Sensitivity to the needs of the customers

A startup image professional's ability to get multiplied business depends on 2 factors

- Time invested in marketing

- Number of clients each client generates

\section{Let us understand the first point}

The time invested in marketing your services is directly proportional to the leads generated. Targeted audience marketing is the key to creating touchdown points and is the most crucial factor in determining the success rate and earning capacity. Since the Image consulting business is all about helping people achieve greater success and sustainability in their professions, it is imperative to create a network of as many people as one can gain visibility of. This automatically converts leads into business.

Targeted marketing points can be created in many ways. Some of the key methods are listed below:

- Offering free workshops to groups of target audience. In our case this can be college students, freshers for jobs, mid level management professionals, retail outlets, NGO's etc.

- Inviting people in your contacts to join you on your social media platforms like Facebook, Instagram, Twitter and LinkedIn. This is a great way to promote your services to a larger group of audience.

- Writing blogs and product recommendations is another way to promote you as an Image professional and slowly build up a social following.

- Participate in various discussion forums on digital media. This instantly gives visibility to your opinion and point of view highlighting your objective as an entrepreneur.

The time spent on promoting your brand across various marketing platforms will enhance your credibility and authenticity up to sustainable standards in the industry.

\section{The second point lays emphasis on a strong referral system.}

The first and foremost thing is to build a brand or a service worth recommending. 
If every single client refers two new clients, your business is bound to have exponential growth. The simplest way recommended to ascertain whether your services are liked by your clients is to get a detailed questionnaire filled and a simple test where you ask the users to rate your services on a scale of 1-10.

Ask specific questions as, "How likely you would recommend our services to a friend?" If your average score is above 9.0, it is likely that you will achieve exponential growth.

Brian Halligan from Hubspot put it best when he said: "To be successful, you must match the way you market your products with the way your prospects learn about and shop for your products" (Brian Halligan, Hubspot).

\section{Conclusion}

Image consulting helps create powerful first impressions to get more opportunities in business. Body language and soft skills play a very important role in betterment of performance when one gets the opportunities.

Identify key audiences for your message and implement marketing plan for brand "YOU", making your digital presence the strongest expression of your personal brand. Social media networks provide a great opportunity to get feedback, build a network and add credibility to your services.

\section{Few important points to consider while choosing a promotional strategy for your brand are}

- Know why you are using it and the endless possibilities that can be explored. You have multiple reasons to justify. Here quantity is not the concern but clarity is.

- Know what works for you. This is possible only by trying and testing various promotional methods before you decide what works best for you.

I would like to wrap up this guide by making a paradoxical point that no points mentioned in this guide are exclusively correct. It's my perspective purely based on my industry experience and learning outcomes over the years.

Each image professional has their own experiences and leanings. I advise experimenting to reach your own conclusions on what works for your business and implement strategies for business growth accordingly. The reason I have been able to put together a consolidated guide is my journey in the field of image consulting over the last 10 years combined with my diversified experience in the aviation industry for the past 16 years.

In the fast moving world where change is constant we must challenge to be adaptable to the ever changing environment and requirements of the industry. 
Resumen: El propósito de este artículo es definir los estándares de sostenibilidad de la industria que prevalecen en la industria de consultoría de imagen para ayudarlo a cumplir con esos estándares y obtener éxito en su profesión de consultoría de imagen. Nunca es demasiado tarde para comenzar a trabajar en el valor de marca de su negocio y llevarlo a los estándares más altos que prevalecen en la industria. Image Consulting se trata de hacer crecer su negocio a través de ideas brillantes y herramientas adecuadas. Como consultor de imagen, deje que su imagen refleje su lado extraordinario. En este artículo compartiremos la experiencia práctica de profesionales de la imagen exitosos de la industria con los lectores para dar una idea realista de su viaje de principio a fin, ayudándole a desarrollar su propio negocio. Este artículo tiene como objetivo ayudar a los lectores a comprender los dilemas y la dinámica del mercado y trabajar para promover un negocio sostenible.

También compartiremos varias opciones de negocios y opciones para construir su negocio a su alrededor.

Palabras clave: consultoría de imagen - estilista de celebridades - estándares de la industria - valor de marca - estándares de sostenibilidad - gestión de imagen - consultor de imagen - negocios exitosos.

Resumo: O objetivo deste artigo é definir os padrões de sustentabilidade do setor prevalecentes no setor de consultoria de imagem para ajudá-lo a cumprir esses padrões e obter sucesso em sua profissão de consultor de imagem. Nunca é tarde para começar a trabalhar no valor da marca da sua empresa e elevá-lo aos mais altos padrões prevalecentes no setor. A Image Consulting trata do crescimento de seus negócios por meio de idéias brilhantes e ferramentas certas. Como consultor de imagem, deixe sua imagem refletir seu lado extraordinário. Neste artigo, compartilharemos a experiência prática de profissionais de imagem de sucesso da indústria com os leitores para fornecer uma visão realista de sua jornada do início ao fim, ajudando você a desenvolver seu próprio negócio. Este artigo tem como objetivo ajudar os leitores a entender os dilemas e dinâmicas do mercado e trabalhar para promover um negócio sustentável.

Também compartilharemos várias opções e opções de negócios para criar seus negócios em torno dele.

Palavras chave: Consultoria de imagem - estilista de celebridades - padrões da indústria - valor da marca - padrões de sustentabilidade - gerenciamento de imagens - consultor de imagem - negócios de sucesso.

[Las traducciones de los abstracts fueron supervisadas por el autor de cada artículo] 